\title{
Exploring University Students' Politeness via Vietnamese Students' Emails of Requests
}

\section{Nguyen Minh Trang}

\section{* Correspondence: \\ nguyenminhtrang@hotmail.com}

Binh Duong University, Vietnam

Received: 3 May 2019

Revision: 8 July 2019

Accepted: 27 July 2019

Published online: 20 September 2019

\section{Abstract}

The study analyzed a corpus of 40 emails of requests composed by Vietnamese students to their university lecturers. The study purpose was to identify politeness strategies composed by Vietnamese students using Brown and Levinson's model and Blum-Kulka, House and Kasper's framework as guidelines. To obtain the results, a discourse analysis was implemented. The AnConc software was used as a research tool for the study. 40 emails from 80 students were collected and divided into three types of requestive emails: assistance, confirmation and consideration, and recommendation for data analysis. Syntactical and lexical modifiers were examined and politeness markers were identified manually by the assistance of the AnConc software. The results indicated that Vietnamese students often used status-stating, deferent and solidary politeness strategies to approach their professors for personal requests. While using these three strategies, the target students had to use syntactical and lexical devices such as modals, interrogatives, please, and hedges as speech acts or supportive moves to gain their requestive purposes. The study also identified a common pattern that Vietnamese students liked to use the email corpus in the direction of salutation, selfintroduction, requests, reasons for request, and thank compliments. The study has pedagogical implications for language teachers and learners; e.g. email writing should be taught to students, especially ESP students as these students do not know the format and the appropriate language they should use in email composition. Language students should also pay attention to the correct formal form and cultural differences when composing requestive emails delivered to their professors.

Keywords: politeness, politeness strategies, positive and negative politeness, emails of requests 


\section{Introduction}

Email has become a popular means of communication between friends and friends, university students and their instructors or professors in academic settings, especially in the age of computer-mediated communication (CMC). Nowadays, email appears to be one of the main modes of student-faculty communication as it is the most convenient means of communication with professors and students instead of making face-to-face contact (Danielewicz-Betz, 2013).

As email is free or at a low cost, it is increasingly used nowadays as a replacement of postal letters. Students send emails to professors to make requests for appointments, seeking advice, asking for scores or course information, or simply asking advice for their study or personal matters. As a result, email is used as a replacement of telephone calls and postal letters. Email, in fact, contains itself features of both spoken and written language (Chen, 2001).

However, it is important to understand that email also has its negative effects of destroying people's relationships, and in educational settings email potentially affects the relationship between professors and students if students do not use correct email etiquettes, with appropriate social interactional norms. Therefore, in making requests to university lecturers or professors, students have to be careful, not merely clicking the email button "send" because email can be offensive (Graham 2007, 2008, as cited in Haugh, 2010; Locher, 2006).

\subsection{Statement of the Problem}

In this paper, I analyzed one particular type of email exchange composed by Vietnamese university students delivered to their lecturers in the form of emails of requests. The study aimed to help students understand the importance of email language that university students should use, especially when they have to write emails of request to their university professors. The research was implemented due to the fact that many students at tertiary level did not pay attention to the format and language use in their email which led to the breakdown of the communication between students and their university professors and could not achieve their requestive purposes.

The study aims to (1) describe different politeness strategies and discourse styles demonstrated in the students' e-mail requests by analyzing general e-mail textual features, information sequencing of requestive events, linguistic realizations of requestive acts, and discourse styles of requests, and (2) to interpret and explain these textual differences from the perspectives of social identities, social relations, and cultural knowledge of politeness strategies.

\subsection{Research Questions}

This study aims to find out the answers to the following two questions:

1. Which politeness terms and politeness strategies are frequently used in emails of requests delivered to university professors by Vietnamese students?

2. Which common patterns do Vietnamese students use in their emails of requests?

\subsection{Research Hypotheses}

The study was then guided by the following hypotheses:

1. Did Vietnamese university students know how to use polite terms and politeness strategies in their emails of requests to their lecturers or professors?

2. Did Vietnamese students use similar email structures in their requestive emails sent to their professors?

\section{Literature Review}

\subsection{Previous studies on email requests}

Chen's (2001) study was implemented with American and Taiwanese graduate students' email requests such as appointments, recommendations, special considerations of faculty whom students either knew or did not know revealed that both groups of students preferred query preparatory (e.g. can you) and want statements (e.g. I want/would like to) to realize their requests, but they differed in amount of lexico-syntactic politeness features (e.g. use of past tense, please, possibly, I was wondering if), showing native speakers' requests more indirect and polite. Chen (2006) observed that the students' ability when making requests to their professors via email improved over time. She noticed 
that the students' requests changed from "primarily want statements to query preparatory strategies" and showed evidence of greater politeness through lexico-syntactic modification.

Bisenbach-Lucas (2007) studied native and non-native speakers of English. This study focused on e-politeness in email requests by students to faculty members. The researcher in this study used Blum-kulka, House, and Kasper's (1989) speech act analysis to investigate the students' emails. Students' email requests were analyzed from the pragmatic and lexico-syntactic point of view, directness of requests, and syntactic and lexical politeness markers. The findings of their study revealed that students applied more direct strategies for the lower imposition request and more politeness devices with direct request strategies (e.g. feedback requests).

Another research was carried out by Rhamani, Rahmany, and Sadeghi (2014) attempting to investigate politeness strategies and politeness markers in email-request sent by Iranian male and female English as foreign language learners to professors. The comparison between strategies used by males and females in email-request were also analyzed. 52 actual emails of M.A. students of TEFL at Takestan Islamic Azad University in Ghazvin province in Iran were collected. To analyze the corpus, politeness strategies in each email were examined according to the strategies adopted by Brown and Levinson's (1978) politeness theory. Finally, the frequency of syntactic and lexical politeness modifiers in each email of requests of male and female were found and compared. Results showed that negative politeness strategy was the most frequent strategy used by males and females in emails. Also, embedding was the most frequent syntactic politeness modifier and subjectivizers were the most frequent lexical politeness modifiers used by both males and females in requestive emails.

Nguyen and Ho (2013) examined requests in Vietnamese speech acts. The researchers examined emails of request delivered by nine Vietnamese native speakers to their lecturers. Data were analyzed with reference to the categorization of Blum-Kulka, House and Kasper (1989)'s framework based on the level of directness, the choice of request strategy, and the use of modification. The findings suggested that unlike requests in some European languages reported in the literature, requests in Vietnamese as a native language were realized predominantly by means of imperatives in equal power situations and query preparatories in low-to-high power situations, regardless of imposition levels. Requests were modified preferably by means of speech acts or supportive moves such as steers and grounders, and lexical means such as address terms, honorifics, modals, and appealers. These findings are discussed with implications for cross-cultural communication and the teaching and learning of Vietnamese as a second language.

Thanh and Le (2012) studied a range of politeness strategies used in making requests in English and Vietnamese and investigated the relationship between politeness and requesting in the light of cross-cultural pragmatics. In the study, strategic requesting employment can be found in specific situations in English and Vietnamese. With the reference to Brown and Levinson's work and Blum Kulka's analyses, two main types of requestive strategies with repressive actions are investigated, namely, positive and negative politeness strategies. The study finds out addressing forms and lexico-modal markers can be the main factors that determine degrees of politeness in making requests. The study hopes to raise awareness in linguistic and cultural differences between two languages and cultures in requesting which boosts further steps in intercultural communication studies in the context of globalization.

In summary, there is quite a number of research on politeness strategies via emails implemented by Western scholars. However, in Vietnam, most researchers focussed their study on politeness and politeness strategies carried out by spoken language. It appears no researches relating to politeness strategies via email requests have been found in the literature review, and this is a good reason for the researcher to implement this research.

\subsection{Politeness Theory}

Politeness theory is one of the most popular theories proposed by Brown and Levinson (1987). The universality explains politeness theory across languages and cultures around the world. Politeness is one characteristic that is essential in considering how to behave with others appropriately according to their social status and social norms. Politeness changes according to cultures and the ways people express politeness are also different across cultures (Patridge, 2006). Therefore, politeness strategies should be used in spoken and written discourses in order to decrease infliction of face threatening acts. The main idea of politeness theory has its roots from Lakoff's (1973) three maxims of politeness: "don't impose", "give opinions" and "make your hearer feel good" (Lakoff, 1973, as cited in Patridge, 2006, p.72). 


\subsection{Politeness Strategies}

Brown and Levinson (1987) divide politeness strategies into two types: positive and negative politeness strategies. Positive politeness strategies aim to satisfy the addressee's wants and enhance his/her self-image. On the other hand, negative politeness strategies aim not to impede or interfere with the addressee's freedom of action. Scollon and Scollon (1995) state that positive politeness is called "solidarity or involvement politeness" while negative politeness is called "deference or independence politeness." However, when talking about politeness, indirectness is often referred to because "the degree of indirectness in requests is closely related to politeness." Researchers claimed that the more indirect a request is, the more polite it is (Brown \& Levinson, 1987; Leech, 1983). Politeness strategies that were established by Brown and Levinson (1987) present the best-known framework for classification of politeness strategies and were applied to many studies around the world so far.

\section{Methodology}

\subsection{Research Design}

This study employed a discourse analysis method. According to Wiggins (2009), a discourse analysis method is essential for assisting interpret human relationship, and how people talk or write to each other. The present study focuses on how students at tertiary level used emails of requests requesting for confirmation and consideration, and email requests for recommendation. All the emails delivered to the two professors in charge of teaching the targeted students in the two academic terms 2012-2013 were stored in the professors' personal email inboxes and then collected for this study.

\subsection{Participants}

80 students who majored in Translation and Interpretation Studies from Ho Chi Minh City University of Education, Vietnam, had joined this study and had written emails to their two lecturers. Their emails were then collected and classified as emails of requests for data analysis which contributed to form a corpus as data for analysis.

\subsection{Research Instruments}

This study used the AnConc software to analyze a corpus of 40 selected emails of requests after classifying these emails into (a) emails of requests requesting for confirmation and consideration, and (b) email requests for recommendation. The AnConc software (www.antlab.sci.waseda.ac.jp/software/antconc341/AntConc.exe) is a freeware, multiplatform tool for carrying out corpus linguistics research and data-driven learning developed by Laurence Anthony in 2014. This software was used to identify the concordance hits of politeness markers that helped recognize the highest frequency of the most commonly used politeness terms used in the participants' emails that answered the first question. The software also helped the researchers of this study in finding out answers to the second question 'Which common patterns do Vietnamese students use in their emails of requests?

\subsection{Data Collection}

A corpus of 40 emails of requests written in English from 80 emails written by 80 Vietnamese third-year students who majored in translation and interpretation studies from Ho Chi Minh City University of Education in Vietnam was selected for this study. These emails belonged to coding schemes suggested by Brown and Levinson (1987) and BlumKulka, House and Kasper (1989). Other emails delivered to the two lecturers which did not belong to the targeted type of requestive emails were not selected for the corpus.

\subsection{Data Analysis}

These emails were privately sent to the two teachers who were also the teachers of the email senders. Emails were then classified into three types: email requests for assistance, email requests for confirmation and consideration, and email requests for recommendation. The emails were then analyzed according to their email distribution or the general features of email such as opening and ending salutations, and the textual features of the main parts of the email. Politeness strategies were identified, using the combination of Brown and Levinson's (1998) model and CrossCultural Speech Acts Realization Project (CCSRP)'s analysis framework recommended by Blum-Kulka, House and Kasper (1989). However, as Blum-Kulla, House and Kasper said, Brown and Levinson's model has its limitations focusing mainly on spoken analysis of Western languages and culture. The study investigated the use of lexical and syntactic devices by Vietnamese students to carry out polite requests. Politeness strategies used in each type of 
classified emails of requests were named, basing on a coding code recommended by the two theoretical frameworks mentioned above (see Appendices A \& B for coding categories).

\section{Findings and Discussion}

\subsection{Findings}

4.1.1 Findings for the First Question: Polite terms and politeness strategies used in Vietnamese students' emails of requests

For email openings, salutation, and self-introduction, Vietnamese students tend to use the formal address terms and formal salutations (Dear Sir, Dear Teacher) to start their messages although their status with their professors is low imposition. The Vietnamese students of this study frequently introduced their first names or full names and their background information (I am Dong Thi to Uyen from Class AV K11; I am Loan from Class Translation and Interpretation $A V$ 02). They called their teachers by their first names and add $\mathrm{Mr} / \mathrm{Sir}$ after Dear (Dear Mr. Trang, Dear Mr Nam) and then introduced themselves. These textual features look similar to Chen's (2001, p.10) requestive email research in which she mentioned email openings written by Chinese students (Table 2).

Table 2. Textual features of email openings by Chinese students

\begin{tabular}{lcccc}
\hline & TS data (60 e-mails) & \multicolumn{2}{c}{ AS data (54 e-mails) } \\
& N of e-mail & $\%$ & N of e-mail & $\%$ \\
\hline Formal address term (title + last name) & 60 & $100 \%$ & 33 & $61 \%$ \\
\hline Salutation (Dear...) & 50 & $83 \%$ & 14 & $26 \%$ \\
\hline Self-introduction & 7 & $12 \%$ & 0 & $0 \%$ \\
1 1) Name only (This is xxx) & 29 & $48 \%$ & 5 & $9 \%$ \\
$\quad \begin{array}{l}\text { (name) \& background } \\
\text { information }\end{array}$ & & & 9 & $17 \%$ \\
\hline Phatic communication \\
(e.g. How are you? Happy New Year!)
\end{tabular}

Vietnamese students also used similar phatic communication as Chinese students used in their emails to their professors (How are you, teacher?) when they approached their professors to build good relationships with the email receivers. The difference recognized between Vietnamese and Chinese emails of requests openings is that Vietnamese students seldom used the formal address term (title + last name) to addresss their teachers. Instead they use the structure 'title + first name' in their email openings (Dear Mr. Trang; Dear Mr. Nam). Like the Chinese students write emails of requests to their professors (Chen 2001), Vietnamese students when composing their emails of requests often used more lexical politeness markers than syntactical politeness markers: these lexical politeness markers include please, subjectivizers, and hedges. Please received 15 concordance hits from the AnConc that is equal to $37.5 \%$ of the 40 -email data. For syntactic politeness modifiers such as modals, interrogatives and embedding were also used by the students of this study (Table 3 ). 
Table 3. Syntactical and lexical modifiers used in this present study

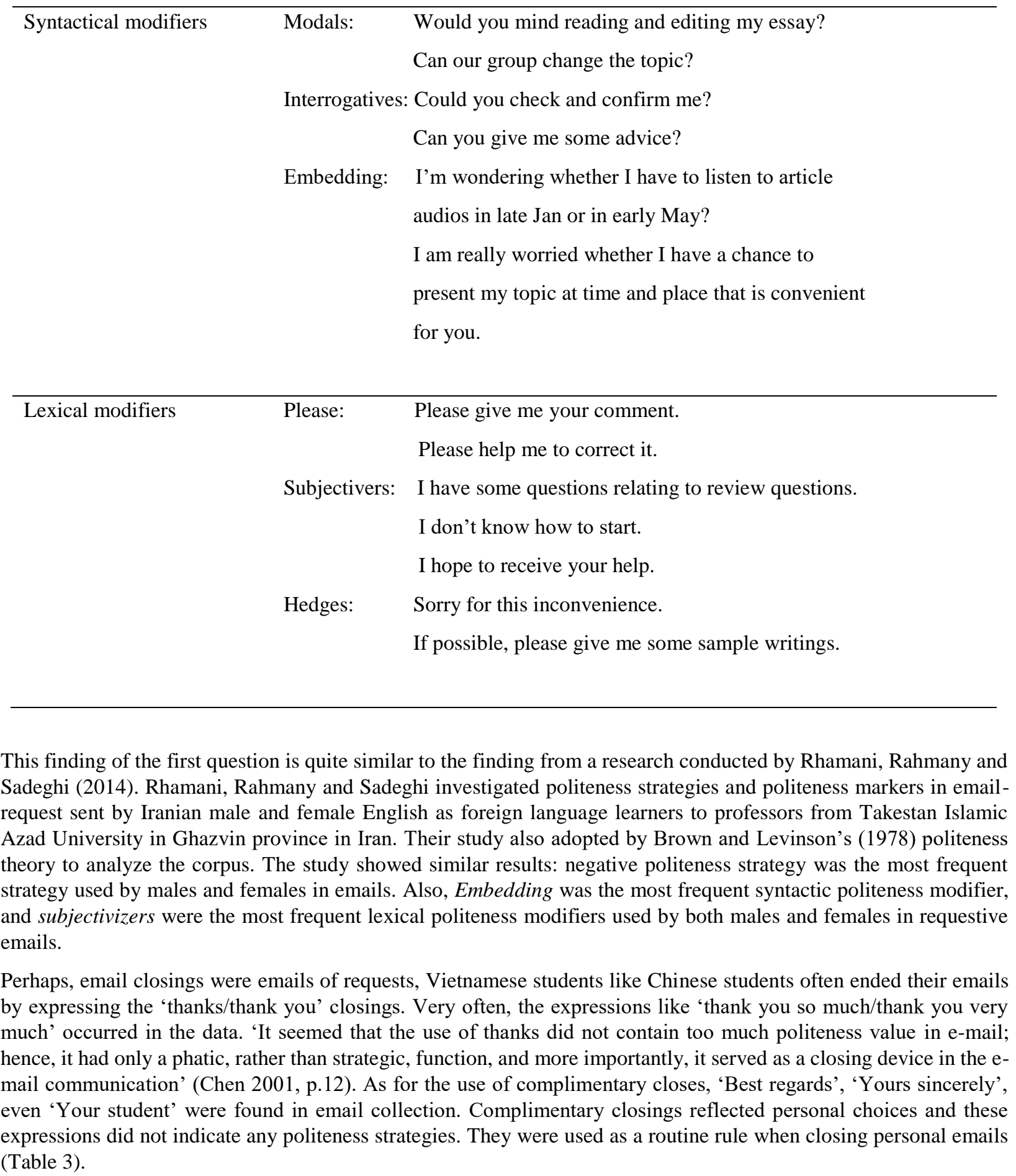
(Table 3). 
Table 4. Textual features of email closings written by Vietnamese students

\begin{tabular}{llll}
\hline Expressions in Closings & $\begin{array}{l}\text { Total emails of requests } \\
(\mathrm{n}=40) \\
\begin{array}{l}\text { Number of } \\
\text { Emails }\end{array}\end{array}$ & Examples \\
& 12 & $30 \%$ & $\begin{array}{l}\text { Thank you very much. } \\
\text { Thank you so much } \\
\text { Thanks for your consideration }\end{array}$ \\
\hline Thank you & 3 & $7.5 \%$ & $\begin{array}{l}\text { Thanks once again } \\
\text { Best, Kind regards, Best regards, Yours } \\
\text { sincerely }\end{array}$ \\
Complimentary close & 6 & $15 \%$ & $\begin{array}{l}\text { Your student } \\
\text { Sign off }\end{array}$ \\
& 3 & $7.5 \%$ & \\
\hline
\end{tabular}

From the above findings, the author finds out there are three commonly-used politeness strategies that Vietnamese students of this 40 email corpus used: 1) status-stating strategies (establish legitimate right to make requests to lecturers), 2) deferent politeness strategy or respectful politeness strategy (by using gift-giving devices, giving compliments, showing appreciation) to elevate and enhance teacher's face and to show respect to lecturers, and 3) a solidary politeness strategy to help students establish relationship or solidary with teachers. All of these strategies were carried out indirectly to serve their politeness strategic purposes. These strategies were implemented by series of speech acts or supportive moves towards the request goals as Patridge (2006) confirms in his study, "Indirectness, then, is often an involvement, or positive politeness strategy" (p.75).

\subsubsection{Findings for the Second Question: Pattern of email requests}

As the textual analysis of different types of emails of requests showed us that there are five main elements formed by different speech acts were identified from the corpus: (1) Addressing, (2) Providing Background/Personal Information, (3) Request, (4) Complimentary, and (5) Closings. Different syntactical and lexical modifiers were used by Vietnamese students, but the same structure of the emails of requests followed this direction. Below is the table detailed the email structure:

Table 5. The structure of email requests

No of Occurrences $\quad \% \quad$ Corpus

$\begin{array}{lllll}\text { 1. } & \text { Opening salutation } & \mathbf{3 0} & 75 & 40 \\ \text { 2. } & \text { Background Info } & 19 & 47.5 & 40 \\ \text { 3. } & \text { Request statement } & \mathbf{2 4} & 60 & 40 \\ \text { 4. } & \text { Expression of complimentary/thanks } & \mathbf{2 0} & 50 & 40 \\ \text { 5. } & \text { Closing salutation } & 9 & 22.5 & 40\end{array}$


These are the five main elements found in most emails of requests in the corpus; however, opening salutation, request statement, and expressions of thanks seem obligatory in the analyzed emails. This structure of requestive emails is similar to the email structure found from Chen's (2001) study. This pattern used by Vietnamese students in this study also goes in line with some other researchers who conducted their study on email requests and politeness expressed by emails or text messages (Gu 1990; Nguyen \& Ho 2013; Tran 2010).

\subsection{Discussion}

As discussed in Data Analysis, there were two kinds of analyses conducted in this study. Firstly, a distribution analysis of general e-mail textual features such as openings and closings was carried out. Secondly, a detailed inter-textual analysis of requestive emails was then implemented. The distribution analysis aims to compare selected emails of requests in the use of address terms (salutation and complimentary close), opening moves (self-introduction, conversational phatic communication) and closing moves (thanks). For the inter-textual analysis, the author of this study chose three kinds of requestive emails for data analysis. They were email requests for assistance, email requests for confirmation and consideration, and email requests for recommendation. The inter-textual analysis focused on the use of a combination of speech acts such as supportive moves, genre types relating to discourse structures, and request perspectives. The findings of the textual and inter-textual analysis were then interpreted and explained from socio-cultural norms of politeness theory and politeness strategies reflected in their e-mails of requests.

\subsubsection{Distribution analysis of general email textual features}

For this section, the researcher investigated the use of formal terms of address, salutation, self-introduction, and greetings as ways to explore the politeness language used by the target Vietnamese students in their emails of requests.

\subsubsection{Openings}

\subsection{Address terms and salutation}

The AnConc software showed 12 concordance hits out of the 40 email corpus that "Dear Teacher" was commonly used by Vietnamese students in their email openings. Other ways of using address terms and salutations such as "Dear + Mr. + full name" (e.g. Dear Mr. Nguyen Van Nam) or "Dear +Mr. +First Name" (e.g. Dear Mr. Nam, Dear Mr. Trang) were also recognized although they were less used by the students. According to Vietnamese culture, Vietnamese students can address a high-status person even by his or her first name (Gu, 1990; Nguyen \& Ho, 2013; Tran, 2010). This method of addressing a person in power or in a higher position or a far distance has its roots from Vietnamese culture to show respect of the addressee to the addresser. According to Brown and Levinson (1987), a speaker can make a choice of address terms either to mark group identity (e.g. mate, buddy, brother, sister) or to 'give deference' (e.g. Sir, Teacher, Professor) to the hearer. In Brown and Levinson's model, address terms can be strategically used to attend to the hearer's positive or negative face wants, based on the speaker's intentions. However, in the Vietnamese language, address terms are an indispensable index of social relationships and expresses respect for and conformity to power and the social hierarchy (Nguyen \& Ho, 2013). Their usage is constrained by the speaker's social role and obligations rather than by his or her intention (Tran, 2010), and this usage is seen as a difference from Western and Chinese cultures (Chen, 2001; Gu, 1990). Thus, Vietnamese students like Chinese students (Chen, 2001) in this email corpus also used the address terms strategically to attend to the professors' positive face wants. Nguyen and Ho (2013) named this way of addressing the hearer/reader "respectful politeness" or "strategic politeness" according to Vietnamese culture.

\subsection{Self-introduction}

$90 \%$ of the email from the corpus started with self-introduction. Vietnamese students started their emails with their names and background information. Self-introduction used by Vietnamese students does not aim to serve the purpose of introducing the students themselves to the addresser as people meet each other for the first time do. Self-introduction used in these emails serves as a strategy to establish legitimate rights before the students to propose their requests to professors. This style of writing is influenced by ways of composing letters recommended by Vietnamese literature and culture (Nguyen \& Ho, 2013). Self-introduction written by Vietnamese students from this study also revealed the fact the terms they used in their emails of requests were similar to those used by Chen' (2001) Chinese students as indicated in Table 6 below: 
Table 6. Textual features of email openings written by Chinese students. Source: Chen 2011, p. 10

\begin{tabular}{lcccc}
\hline & $\begin{array}{c}\text { TS data (60 e-mails) } \\
\text { N of e-mail }\end{array}$ & $\%$ & AS data (54 e-mails) \\
& 60 & $100 \%$ & 33 & $61 \%$ \\
\hline Formal address term (title + last name) & 50 & $83 \%$ & 14 & $26 \%$ \\
\hline Saltutation (Dear) & 7 & $12 \%$ & 0 & $0 \%$ \\
\hline Self-introduction & 29 & $48 \%$ & 5 & $9 \%$ \\
1) Name only (This is $x x x$ ) & & & & \\
2) (name) \& background information & 11 & $18 \%$ & & \\
\hline Phatic communication & & & & \\
(e.g. How are you? Happy New Year!) & & & & \\
\hline
\end{tabular}

The merely difference between Vietnamese students' email opening and Chinese counterparts is the use of 'Formal address term.' Instead of using 'Title + last name', Vietnamese students tended to use 'Title + First name' in their requestive emails (e.g. Dear Mr. Trang instead of Dear Mr. Nguyen). Therefore, the email openings composed by 40 target students of this study are shown in Table 7 below:

Table 7. Textual features of email openings written by Vietnamese students

\begin{tabular}{|c|c|c|c|}
\hline & \multicolumn{2}{|c|}{$\begin{array}{l}\text { Total emails of requests } \\
(\mathrm{n}=40)\end{array}$} & \multirow[t]{2}{*}{ Examples } \\
\hline & $\begin{array}{l}\text { Number } \\
\text { of } \\
\text { Emails }\end{array}$ & Percentage & \\
\hline Formal address terms & 40 & $100 \%$ & Mr. Trang \\
\hline (Title + first name) & & & Teacher \\
\hline \multirow[t]{2}{*}{ Salutation (Dear...) } & 38 & $95 \%$ & Dear Mr. Trang \\
\hline & & & Dear Teacher \\
\hline Self-Introduction & 36 & $90.5 \%$ & My name is Nguyen Thi Lan \\
\hline a) First name (I am.../My name is...) & & & I am Nga \\
\hline b) Name \& personal info & & & My name is Dong Thi To Uyen \\
\hline Phatic communication & 27 & $67.5 \%$ & How are you, teacher? \\
\hline (How are you?) & & & How is your family? \\
\hline
\end{tabular}

\subsection{Phatic communication}

Emails of requests from the corpus revealed that Vietnamese students often used conversational phatic communication such as "How have you been you?" or "How's your teaching?" in the first paragraph of their emails. This way of writing is considered a usual conventional phatic communication because it bears a characteristic of a conversation rather than transactions or interactions, instead of launching straight into requests as Westerners do in making requests (Murray,1995). According to Bisenbach-Lucas (2007), Western students tend to use direct strategies to approach their 
professors for requests, but Vietnamese students like to use conversational phatic sentences before mentioning their requestive information (Nguyen \& Ho, 2013; Thanh \& Ho, 2012). This way of composing emails seemed to violate Grice's (1975) maxim of relation "be relevant" and the maxim of manner "be as clear, as brief, and as orderly as one can." However, Chen (2001) said Chinese students also used this "solidarity politeness" as a strategy to enhance their intimacy with their professors (p.10).

\subsubsection{Closings}

There are two typical types of closings used in the email corpus: thanks/thank you and complimentary closes. Expressions of "thanks", "thank you" and "thank you very much" are commonly used in the email data (Table 1). This use of thank closings can be recognized as a polite norm universally used, especially in this case, all emails are related to requests made to professors. However, the application of thanks was used very differently from each Vietnamese student. The patterns of "thank you", "thank you very much", or "thanks for" are shared among requestive emails written by the target students (Nguyen \& Ho, 2013; Thanh \& Ho, 2012).

In summary, the findings from the openings and closings of requestive emails in the openings and closings revealed that Vietnamese students used formal address terms and salutation to show deferent politeness to email receivers. However, the syntactic structures of the expressions in openings and closings are mixed up between informal and formal languages due to their lack of knowledge on writing styles. The study also discovered that Vietnamese students, while writing emails, carefully think of the distance and the role between the email sender and the email receiver so that they could use appropriate terms to convey the polite meanings of their e-messages (Table 8).

Table 8. Textual features of email closings

\begin{tabular}{llll}
\hline Expressions in Closings & \multicolumn{1}{c}{$\begin{array}{c}\text { Total emails of requests } \\
(\mathrm{n}=40)\end{array}$} & Examples \\
& $\begin{array}{l}\text { Number } \\
\text { Emails }\end{array}$ & of Percentage & \\
\hline Thank you & 12 & $30 \%$ & $\begin{array}{l}\text { Thank you very much. } \\
\text { Thank you so much }\end{array}$ \\
Thanks & 3 & $7.5 \%$ & $\begin{array}{l}\text { Thanks for your consideration } \\
\text { Thanks once again } \\
\text { Complimentary close }\end{array}$ \\
Sign off & 6 & $15 \%$ & $\begin{array}{l}\text { Bind regards, Best regards, Yours } \\
\text { sincel }\end{array}$ \\
& 3 & $7.5 \%$ & Your student
\end{tabular}

4.3 Inter-textual analysis of different types of emails of requests

From the corpus of emails of requests, there are three common types of requestive emails recognized. The biggest type of email requests is related to emails asking teachers for assistance (21 emails). The second type of emails is about emails requesting for consideration and confirmation (17 emails), and the third type of emails is about emails asking for recommendation ( 2 emails). Each type of email requests was selected for textual analysis. For textual analysis, syntactical and lexical devices and politeness markers would be identified in the emails to help find out different politeness strategies used by the target Vietnamese students. Finally, a common pattern or a common structure of the three types of emails of requests would be recognized. 


\subsubsection{Type \# 1: Emails requesting for assistance}

There are two main parts (1) self-introduction and 2) asking for help discovered from 21 emails of this type. In the self-introduction, Vietnamese students, unlike native speakers of English, wrote much about their names, classes, courses, departments they belonged to. This way of writing sounds like personal narratives. Then the students stated the requestive purposes and ended their emails with thanks and complimentary closings.

(1) "I am Quy Ngoc, a student in SIU, course 4, in the morning class."

(2) "I'm Quynh Nhu, student of 4TMB (course 35) English Department, HCM City University of Education."

An analysis of the reasons leading to their requests revealed that emails of this type followed the sequence of "becausetherefore" as Vietnamese students gave reasons and asked for help.

(3) "I think it has some mistakes, but I have tried my best. Therefore, would you mind reading and editing my essay for me?"

In one of the emails from this corpus, a Vietnamese student wrote:

(4) "During my junior, I studied the subject Interpretation with you and I really like this subject.."

This compliment is considered as a positive politeness strategy called "gift-giving" politeness strategy - the terms used by Brown and Levinson (1983). This type of politeness strategies was recognized in many emails from the corpus. For the pre-close section, Vietnamese students used "I am looking forward to hear your reply" as an optimistic point of view of positive politeness by Scollon and Scollon (1995). The aim of this positive politeness strategy is to gain solidarity and involvement politeness with hearers, in this case, with the two university lecturers.

4.3.2 Type \# 2: Emails requesting for confirmation and consideration

Vietnamese students still used self-introduction in their opening salutation as they did in emails asking for assistance:

(5) "...you have mentioned that the exam day is on $14^{\text {th }}, \mathrm{Feb}, 2009$. This is so strange because according to the schedule of HOU on the website it is on $7^{\text {th }}$, Feb, 2009" or "so I am wondering whether they are Oct and Nov, or Nov and Dec?"

Students gave optional solutions to teachers for consideration or confirmation:

(6) "Could you check and confirm for us this - whether on $7^{\text {th }}$ or 14th?"

Syntactical devices such as modals, interrogatives were found in most of the emails asking for consideration or confirmation:

(7) "Can my group change the topic?"

(8) "Would you mind reading and editing my essay?"

(9) "Could you check and confirm me?"

A deferent politeness strategy to the addressee is used in one of the students' emails.

(10) "I hope that such questions will not bother you and I am looking forward to your response."

In an email, it is worth noticing that a Vietnamese student also gave her business contact to the teacher to confirm her request. This style of requestive email writing makes her academic emails look like a business email. A common pattern with supportive speech acts was recognized in this type of emails: situation-problem-solution 1-reject -solution 2.

4.3.3 Type \#3: Emails requesting for recommendation

This type of emails of requests received a small number of emails delivered to two lecturers. Vietnamese students composed their emails requesting teachers to write recommendation letters to gain a scholarship to participate in an exchange program devoted to Vietnamese students from a university in Korea. Terms of address (e.g. "Dear +Teacher", "Dear + Mr. + first name") and self-introduction (e.g. My name is Đồng Thị Tố Uyên, a student of Class $4 B P D .09$, and I'm taking your Interpretation course that you are in charge) were also used by Vietnamese students of this group and the sequence of information used in these emails also followed the pattern "because-therefore." 
(11) "I really want to join this exchange program to widen my knowledge. Therefore, I write this letter to ask your introduction to school as a recommendation letter needed for my application."

They ended emails with complimentary closes:

(12) "I really hope you agree with my idea."

(13) "I am looking forward to hearing from you soon."

and signed off. This complimentary was used to express the student's appreciation of her lecturer, hoping she could attain her requestive purpose. This strategy is clearly a positive politeness strategy this Vietnamese student used aiming to enhance her teacher's face. This is different from the negative politeness strategies used as the most frequent strategies by male and female students from Iran recorded by Rahmani, Rahmany and Sadeghi (2014)'s research. The sequence of speech acts forming a common pattern for this type of emails of requests was also discovered: selfintroduction, reasons of request.

\section{Pedagogical Implications of the Study}

The pedagogical implication of this study is that in order to avoid misunderstandings or breakdown of email communication occurs between university professors and students at tertiary level, email writing should be taught to students, especially ESP students as these students do not know the format and the appropriate language they should use in email composition. Teachers of email writing should also remind ESP students of the correct formal form of email used for their professors' communication, particularly in the case of requestive emails as this research has pointed out in the findings. When teaching university students compose their email writing, differences in culture that produce different politeness strategies should also be emphasized.

\section{Conclusion}

The study used both Brown and Levison's politeness theory and Blum-Kulka, House and Kasper's CCSRP framework as guidelines for investigating the syntactical and lexical modification employed in forty emails of requests. Politeness strategies were examined throughout email openings, closings and the main body of the emails. Results revealed that Vietnamese students often used lexical modification devices to obtain indirect politeness strategies from their requests more often than syntactical modification due to the lack and complexity of the English structures that make the target students of this research felt difficult to perform their requestive tasks. Therefore, a limited number of syntactical modifications such as interrogatives, embedding, and modals were used. However, Vietnamese students often used elaborate phatic elements and thanking elements to achieve their positive politeness strategies. A common structure from the three types of emails of requests used in most Vietnamese emails in the corpus was found in the direction of salutation, self-introduction, requests, reasons for request, and thank compliments.

The study also found out that Vietnamese students tend to use more indirect politeness strategies to achieve their requestive goals, and this could have its roots from Vietnamese cultures of politeness performance; therefore, when composing e-requests, Vietnamese students tended to look at other factors such as the role and the distance of the addressee and addresser to structure their personal requests. Errors were spotted here and there in the analyzed emails with some writing styles recognized as informal that are not suitable to be included when composing e-requests to university professors. These errors may affect the politeness characteristics the writers wanted to employ in their request messages. The study was implemented within a corpus of 40 emails of requests affordable to be selected that is viewed as limitations of this study. In the future, it would be also interesting to investigate more emails composed by university students from other academic fields of study from different genders and different ages to their lecturers and professors. Perhaps with these new target students, more different strategies may be used in emails that are worthy of future research.

\section{References}

Biesenbach-Lucas, S. (2007). Students writing e-mails to faculty: An examination of e-politeness among native and non-native speakers of English. Language Learning \& Technology, 11(2), 59-81. https://scholarspace.manoa.hawaii.edu/bitstream/10125/44104/1/11_02_biesenbachlucas.pdf

Blum-Kulka, S., House, J., \& Kasper, G. (1989). Investigating cross-cultural pragmatics: An introductory overview. In S. Blum-Kulka, J. House, G. Kaper (Eds.), Cross-cultural pragmatics: Requests and apologies (pp.1-34). 
Volume $4, \quad$ Number $44 \quad$ (2013). $\quad$ Norwood, $\quad$ NJ: $\quad$ Ablex. https://www.academia.edu/11400588/Arab_Word_English_Journal_Volume_4_Number_4_December_2013

Brown, P., \& Levinson, S. (1987). Politeness: Some universals in language usage. Cambridge, MA: Cambridge University Press. https://www.academia.edu/26395652/Politeness_Some universals in language usage

Chen, C. F. E. (2001). Making E-mail requests to professors: Taiwanese vs. American students. Paper presented at the Annual meeting of the American Association for Applied Linguistics (St. Louis, MO February 2001). https://www.researchgate.net/publication/265233090_Making_Email_Requests to Professors_Taiwanese_vs_American_Students

Chen, C. F. E. (2006). The development of e-mail literacy: From writing to peers to writing to authority figures. Language Learning \& Technology, 10(2), 35-55.

Danielewicz-Betz, (2013). (Mis)use of email in student-faculty interaction: Implications for university instruction in Germany, Sauda Arabia and Japan. The JALT CALL Journal, 9(1), 23-57. https://files.eric.ed.gov/fulltext/EJ1107960.pdf

Gu, Y. (1990). Politeness phenomena in modern Chinese. Journal of Pragmatics, 14, 237-257. http://www.u.arizona.edu/ kepeng/EastAsianCulture/Readings/R26.pdf

Haugh, M. B. (2010). When is an email really offensive? Argumentativity and variability in evaluations of $\begin{array}{lllll}\text { impoliteness. Journal of } & \text { Politeness }\end{array}$ https://www.academia.edu/5892068/When_is_an_email_really_offensive_Argumentativity_and_variability_i $\underline{\mathrm{n} \text { evaluations of impoliteness }}$

Klum-Kulka, S. (2007). Students writing emails to faculty: an examination of e-politeness among native and nonnative speakers of English. Language Learning \& Teaching, 11(2), 59-78. https://scholarspace.manoa.hawaii.edu/bitstream/10125/44104/1/11_02 biesenbachlucas.pdf

Lakoff, R. (1973). The logic of politeness; or minding your p's and q's. Papers from the Ninth Regional Meeting of the Chicago Linguistic Society. Chicago: Chicago Linguistic Society, 292-305.

Leech, G. (1983). Principles of pragmatics. London: Longman.

Murray, D. E. (1995). Knowledge machines: Language and information in a technological society. New York: Longman.

Nguyen \& Ho (2013). Requests and politeness in Vietnamese as a native language. Pragmatics, 23(4), 685-714. https://www.researchgate.net/publication/265913115_Requests_and_politeness_in Vietnamese as a native language

Rahmani, E., Rahmany, R., \& Sadeghi, B. (2014). Politeness strategies and politeness markers in email-requests sent by Iranian EFL learners to professors. International Journal of Language Learning and Applied Linguistics World, 5(1), 183-197.

Paltridge, B. (2006). Discourse analysis. London: Continuum.

Scollon, R., \& Scollon, S. W. (1995). Intercultural communication: a discourse approach. Cambridge University Press.

Thanh, D. T. M., \& Le, T .T. Q. (2012). Some differences in requesting strategies in English-Vietnamese. Paper presented Hanoi Ut University, Vietnam. https://s3.amazonaws.com/academia.edu.documents/16870413/proceeding iclc2011.pdf?response-contentdisposition=inline\%3B\%20filename\%3DOrthographic_Customizations_in_Online_Co.pdf\&X-AmzAlgorithm=AWS4-HMAC-SHA256\&X-AmzCredential=AKIAIWOWYYGZ2Y53UL3A\%2F20190718\%2Fus-east-1\%2Fs3\%2Faws4 request\&X-AmzDate $=20190718 T 012127 Z \& X$-Amz-Expires $=3600 \& X$-Amz-SignedHeaders=host $\& X-A m z-$

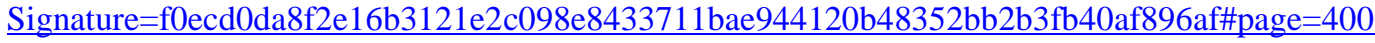


Tran, V. M. Y. (2010). Vietnamese expression of politeness. Griffith Working Papers in Pragmatics and Intercultural Communication, 3(1), 12-21. https://vi.scribd.com/document/269285729/2-Tran-Vietnamese-Expressions-ofPoliteness

Wiggins, S. (2009). Discourse analysis. In: Encyclopedia of human relationships. Sage Publications, California, USA, pp. 427-430. https://www.academia.edu/people/search?utf8=\%E2\%9C\%93\&q=discourse+analysis 


\section{Appendices}

Appendix A: Coding Scheme for Positive and Negative Politeness

Strategies of Positive Politeness

Strategy

Example

(P+1): Notice, attend to $\mathrm{H}$ (his interest, wants, needs, goods) Your skirt is lovely, where did you get it?

$(\mathrm{P}+2)$ : Exaggerate (interest, approval, sympathy with $\mathrm{H}$ ) How absolutely extraordinary!

$(\mathrm{P}+3)$ : Intensify interest to $\mathrm{H}$

You always do the dishes! I will do them tonight

$(\mathrm{P}+4)$ : Use in-group identity markers Hello mate, long time no see!

$(\mathrm{P}+5)$ : Seek agreement How about a match last night? Did Real Madrid play well or what?

$(\mathrm{P}+6)$ : Avoid disagreement

I will meet you at 11 , then

$(\mathrm{P}+7)$ : Presuppose/raise/assert common ground

Oh, this is lovely! (walking into a house)

$(\mathrm{P}+8)$ : Joke

How about lending me those diamonds?

$(\mathrm{P}+9)$ : Assert or presuppose S's knowledge of and

I know you wanted the last book by Paxman but

Concerns for H's wants

$(\mathrm{P}+10)$ : Offer, promise

$(\mathrm{P}+11)$ : Be optimistic

they didn't have it so I got you this one instead

I will send you those documents next week!

I will talk to you soon

$(\mathrm{P}+12)$ : Include both $\mathrm{S}$ and $\mathrm{H}$ in the activity

$(\mathrm{P}+13)$ : Give (or ask for) reason

We are a bit tired, aren't we?

$(\mathrm{P}+14)$ : Assume or assert reciprocity

I am really late for the interview, so...

I will help you with your Spanish I hope you can do

the same with my English

$(\mathrm{P}+15)$ : Give gifts to $\mathrm{H}$ (goods, sympathy, understanding, I hope you are not too stressed with your exams cooperation)

\section{Strategies of Negative Politeness}

Strategy

(P-1): Be conventionally indirect

(P-2): Questions, hedges

(P-3): Be pessimistic

(P-4): Minimize the imposition, $\mathrm{R}$ I just dropped by for a minute to ask you.

(P-5): Give deference

(P-6): Apologize

(P-7): Impersonalize $\mathrm{S}$ and $\mathrm{H}$

(P-8): State the FTA as a general rule

(P-9): Nominalize

(P-10): Go on record as incurring a debt, or as not indebting H I'd really appreciate it if you would...

\section{Example}

Can you please tell me the time?

This may not be relevant but...

Could you set the table?

Excuse me, sir, would you mind if I close the window?

I do not want to bother you, but Is it possible to ask for a favor?

We do not eat with our hands, we eat with knives and forks

We urgently require your help

(Adapted from Brown and Levinson (1987) as cited in Vinagre (2008), p. 1034) 


\section{Appendix B: CCSRP Coding Categories for Direct and Indirect Politeness Strategies by Blum-Kulka, House} \& Kasper (1989)

\begin{tabular}{lll}
\hline CCSARP & Request Strategies & Examples \\
Directness Levels & & \\
\hline Direct & Imperatives & Please extend the due date. \\
& Elliptic constructions & Any comments? \\
& Performatives & I feel I have to ask for an extension for a week. \\
& Direct questions & When do you have time? \\
& Want statements & I want to set up a meeting with you. \\
& Need statements & I will need an extension. \\
& Expectation statements & I hope you'll give me the weekend to finish typing my work. \\
Qunventionally preparatory (ability, & Could I meet with you next Tuesday? \\
indirect & willingness, permission) & Would you mind to take a look and give me some \\
& & suggestion? \\
Hints & Strong hints/mild hints & Attached is a draft of my grammar lesson plan. \\
& & I'm having a very difficult time in figuring out how to put \\
& & these lesson materials together. \\
\hline
\end{tabular}

